\title{
Sphingomyelin Phosphodiesterase 4
}

National Cancer Institute

\section{Source}

National Cancer Institute. Sphingomyelin Phosphodiesterase 4. NCI Thesaurus. Code C105039.

Sphing omyelin phosphodiesterase 4 ( $827 \mathrm{aa}, \sim 93 \mathrm{kDa}$ ) is encoded by the human SMPD4 gene. This protein is involved in sphingomyelin catabolism. 